\title{
Problems and Countermeasures of Flight Attendant Cultivating in Chinese Colleges
}

\author{
Jin Heng \\ Xi'an Aeronautical Polytechnic institute, Shaanxi, China, 710089
}

Keywords: flight attendant; cultivating mode; professional construction

\begin{abstract}
With the rapid development of China's national economy, China's civil aviation industry has ushered in a great opportunity for development. In the context of the sharp increase in the demand for civil aviation talents, the airline's demand for flight attendants, especially excellent flight attendants, has increased dramatically. As an important training channel for flight attendants, colleges and universities have transported a large number of flight attendants for aviation companies for more than a decade. However, due to the relatively short construction time of the airline specialty in Chinese colleges and universities, many aspects are still in the stage of exploration, and many common problems need to be resolved. This paper researches and discusses the problems and countermeasures of the professional cultivating of flight attendants from aspects of enrollment, curriculum setting, teaching methods, practice training, which is of important practical significance for running flight attendant program, and cultivating high-quality flight attendants.
\end{abstract}

\section{Introduction}

With the rapid socio-economic development, China's civil aviation industry has developed rapidly, and the demand for flight attendants has increased dramatically [1]. At the same time, the competition among civil aviation companies has become increasingly fierce. Colleges as an important channel for the cultivating of flight attendants transported large number of talents to airlines. However, due to the relatively short construction time of flight attendants, colleges are still at the exploratory stage in recruiting, curriculum setting, teaching methods, practice training, and student management. There are still many common problems that need to be solved. Therefore, the research of existing problems and countermeasures of the professional cultivating colleges has important practical significance for the airline professional training, the improvement of air service quality, and the improvement of the core competitiveness of airlines.

\section{Problems in the Cultivation of Flight Attendant Talents in Colleges and Universities}

\subsection{Imperfect curriculum system}

Although many colleges and universities in China have set up the profession of flight attendants, the system of talent training has been gradually improved, so far, no specific national professional steering committee has been established [2]. Although there are many colleges that recruit flight attendance students, the major of flight attendance are only anchored under other majors, and professional development lacks theoretical guidance. And the current flight attendance teaching programs for colleges are all improved on the basis of related professional teaching programs, or the combination of music majors and flight attendance majors, or combined with public relations secretary, transportation, art design, broadcasting and hosting, tourism management. The teaching plan lacks systematicnes and integrity. The curriculum is not well-targeted and is not suitable for the airline's demand for flight attendants. Even if some courses meet the requirements of the airline, they cannot agree with the airline. Airlines often have 40 to 180 days of induction training after new hires. Many training courses are similar to flight attendants in colleges. This not only results in wasted educational resources, but also less enthusiasm for student learning. 


\subsection{Insufficient attention to students' psychological quality}

When colleges take airline student admissions, the initial test in the interview is basically based on visual inspection to examine the student's physical appearance and artistic performance. The reexamination focuses on whether the student's physical condition meets the relevant medical examination standards in China and also further examines students. And the language communication and the ability to solve problems in a random manner, but for students is suitable for the service industry, whether there is a psychological quality of service work, there is no corresponding inspection tools and inspection items [3]. This resulted in some of the students admitted that after understanding the substantive content of the flight attendant service, they thought that flight attendants are kind of waiters, and the work was hard, which caused the students' interest in the flight attendants to decline, and also caused the low work enthusiasm of the flight attendants, or they switch to work within a short period of time, resulting in the waste of educational resources and the loss of flight attendant talents.

\subsection{Single teaching mode}

Because the flight attendant major is a new major, and due to the short running time in colleges, the faculty is not very sound and reasonable. At present, most of colleges flight attendant professional teachers come from the specialties related to flight attendants, but lack of practical work experience, some teachers have multiplying experience but lack theoretical foundation, so there is a phenomenon of disconnection between theory and practice in the course of teaching. In addition, the lack of excellent teaching materials, authoritative textbooks and self compiled teaching materials, the imperfect construction of practice training room and the single teaching methods and teaching means have led to the lack of multi form teaching mode of flight attendants.

\subsection{Weak practical training}

Aviation service is very practical. Colleges should construct a perfect practical teaching system in accordance with the principle of full-process practice, and practice teaching goes through all aspects of teaching. This requires stable and convenient on-campus training sites and off-campus practice bases. However, at present, many colleges have little or no specialty building time, some lack professional funding, others lack of aviation background. There are no or few service monitoring standards and innovation monitoring and analysis laboratories, air crew talent quality research laboratories, and simulation cabin laboratories, physical training rooms, flight attendants' voice broadcasting training rooms, makeup training rooms and other on-campus training laboratories did not establish stable off-campus practice bases [4]. In this way, some students do not only lack the necessary practical steps during their studies in school, but also do not have the opportunity to practice. This is not only unfavorable to students' theoretical knowledge learning, but also cannot master the practical operation skills, making it difficult for students to quickly adapt to the needs of the airline.

\subsection{Insufficient service awareness}

Air crew is a typical service occupant, which requires the crew to have a strong sense of comprehensive service first. At present, the students majoring in flight attendants are enrolment according to the art class, while the main sources of art are concentrated in the cities, and the family conditions are relatively superior, and the vast majority of them are only children. Children growing up in this background are often self-conscious, lack of considerate and considerate service quality for others. Their sense of teamwork, service awareness, poor organizational discipline, poor interpersonal skills, and poor tolerance of frustration have brought trouble to the management and teaching of schools, resulting in more difficulty in school management and the other side. It is not conducive to the improvement of the service level of flight attendants, and is not conducive to the improvement of airline service quality. 


\subsection{Insufficient attention to language skills}

The main occasion for flight attendants is to communicate and serve face-to-face, so the acceptance and transmission of various language information is the most important tool for field service [4]. Language ability is a system ability, which includes not only sound language such as Mandarin, local and other languages, but also body language, space language, object language, and sub-language. Learning or mastering a language will make our language more accurate and more charismatic when communicating. While emphasizing the good command of Mandarin and English, schools should also pay attention to the cultivation of some small languages, dialects and body language according to the teachers' situation and the interest of the students.

\section{Countermeasures for the Cultivation of Flight Attendants}

\subsection{Optimize the curriculum system}

For the lack of systematic and integral teaching plan in colleges and universities, the curriculum setting is not pertinent, and it is not suitable for the airline's demand for flight attendants. Although some courses are in line with the requirements of the airline companies, they cannot achieve the mutual recognition of courses with airlines. Airline managers, industry experts, and full-time airline passengers can be hired to serve as professional guest teachers in colleges and universities. On the one hand, they are invited to provide opinions and suggestions on professional reforms and invite them to participate in the formulation, revision, and improvement of instructional programs.

\subsection{Strengthen the cultivation of psychological quality}

For some students lack the psychological quality of engaging in air service, on the one hand, colleges should introduce psychological quality assessment on the basis of the original conditions of admission to improve the quality of students. On the other hand, colleges should strengthen the cultivation of students' psychological quality. Through adjusting course settings, reforming teaching methods, and reforming students' daily management methods, flight attendants learn about the profession through education and education, and finally have deep affection for their profession. Only if students have good psychological qualities can they adapt to the special service of air service and reduce the wastage rate of flight attendants.

\subsection{Reform the single teaching model}

There is a general disconnection between theory and practice in professional teachers in colleges, and the teaching model is relatively single. To improve teaching quality, it should reform the single classroom teaching model and carry out multiple forms of interactive communication teaching model. The following methods could be used as showed in table 1 .

Table1. Multiple forms of interactive communication teaching model

\begin{tabular}{cl}
\hline No. & \multicolumn{1}{c}{ Measurements } \\
\hline 1 & $\begin{array}{l}\text { Employs airline crew managers and experts as part-time teachers } \\
\text { Distributing professional teachers to airlines to gain more practical } \\
\text { knowledge to combine theoretical knowledge and practice }\end{array}$ \\
3 & $\begin{array}{l}\text { Realizing the networking of teaching and realizing the sharing of } \\
\text { high-quality resources on campus }\end{array}$ \\
\hline
\end{tabular}

\subsection{Strengthen practical skills training}

Experimental training is the key step to improve students' practical skills and creativity. On the one hand, colleges should continuously improve the construction of practical training laboratory and experimental equipment, thus to comprehensively improve the overall quality of students and provide training for new types of talents that meet the development needs of modern aviation industry [5]. On the other hand, the condition of the off-campus airline training base is relatively perfect, which 
provides a guarantee for training service-oriented and management-type talents and improving students' practical ability. Colleges should strengthen exchanges and cooperation with aviation companies, establish stable and reliable practice bases, ensure the smooth conduct of professional internships, and strengthen practical skills training to train graduates who can take up posts as soon as possible.

\subsection{Strengthen the cultivation of service awareness and language skills}

Through the reform and exploration of students' daily management mode, practice management and other links, Omni-directional students' service awareness and service ability are strengthened. Guide students to learn one or two dialects based on their language foundation and interests, which is not only reflects the characteristics of the major in colleges, but also enhances the airline passengers' ability to communicate and improve service quality.

\section{Summary}

As an important channel for training flight attendants, colleges have trained a large number of flight attendants for airlines. However, under the background that more and more colleges across the country are rushing to establish flight attendant specialties, the cultivation of aerial crew professionals, especially cultivating the flight attendant talents still faces many problems. Only by taking corresponding measures from professional ownership, teacher building, curriculum setting, and employment mode, can the goal of training high-quality flight attendants and improving the core competitiveness of airlines be achieved.

\section{Acknowledgement}

The backbone Specialty Construction Project of the Action Plan for Innovation and Development of higher Vocational Education-aerial crew Specialty Project No.: XM-1-2

\section{References}

[1] Liu Shijin. Research on current status of air crew professional development in colleges in China[J]. Contemporary education theory \& practice, 2011(8), p.83

[2] LI Guang-chun. Problems and suggestions on cultivating students majoring in flight attendance[J]. Journal of civil aviation flight university of China, 2010(5), p.20

[3] Chang Jing. Research on the training mode of undergraduate art type flight attendants[J]. Journal of Northwestern Polytechnical University, 2011(12), p.99

[4] Liu Shijin. Reflections on the upsurge of aircrew occupation professionals in colleges[J]. Journal of Civil Aviation Flight University of China, 2010(6), p.32

[5] Liu Hui. Research on China's civil aviation air crew countermeasures[J]. Aviation science and technology, 2001 (1), p.20 